\title{
Consequences of Poor Access to Dental Care in Adult Patients with Sickle Cell Disease
}

\section{Samip Master and Richard Preston Mansour ${ }^{*}$}

Department of Medicine, Section of Haematology and Oncology, Louisiana State University Health Sciences Center, Shreveport LA, USA

*Corresponding author: Richard Preston Mansour, Department of Medicine, Section of Haematology and Oncology, Louisiana State University Health Sciences Center, Shreveport LA, USA, Tel: 318-813-1291; E-mail: rmanso@Isuhsc.edu

Received date: February 14, 2018; Accepted date: August 31, 2018; Publication date: September 05, 2018

Copyright: (C2018 Master S, et al. This is an open-access article distributed under the terms of the Creative Commons Attribution License, which permits unrestricted use, distribution, and reproduction in any medium, provided the original author and source are credited.

\begin{abstract}
Sickle cell disease (SCD) is the most prevalent genetic disease in the United States. The patients with SCD are prone to dental problems due to vasoocclusion, increased risk of infection and structural bone changes. There are no specific guidelines for the management of dental problems in SCD. We did a survey on adult patients with SCD to evaluate the prevalence of patient reported dental problems, including existing "bad tooth", and tooth abscess. We also investigated the prevalence of dental insurance that pays for regular dental exams. We found that, only $33 \%$ had their last dental exam within a year and a third of them had more than 2 adult teeth removed. Large number $(41 \%)$ of the patients reported that they currently had tooth ache or have a bad tooth. We also found that only $33 \%$ of the adults with SCD had the dental insurance to pay for dental care. On further analysis, it was found that adults with dental insurance had more dental exams and fewer episodes of dental abscess or bad teeth. Dental care remains a significant unmet need in this special population who are at risk of various dental disorders.
\end{abstract}

Keywords: Sickle cell disease; Sickle haemoglobin; Vaso-occlusion; Dental problems; Jaw swelling

\section{Introduction}

Sickle cell disease (SCD) is an autosomal recessive disease characterized by haemoglobin defect which leads to vaso-occlusive crises. In the United States, SCD affects approximately 100,000 Americans and SCD occurs among about 1 out of every 365 AfricanAmerican births. SCD is a major public health concern. Although in 1970 the estimated median survival for subjects with SCD was just 20 years, today many with SCD are living well into adulthood [1]. In a study involving 3764 patients with SCD (homozygous for sickle haemoglobin), the median age at death was 42 years for males and 48 years for females [1]. The vaso-occulsive phenomenon in SCD can lead to acute pain crises, strokes, acute chest syndrome, dactylitis and also complication in pregnancy. The vaso-occlusive phenomenon can also affect the dental health of the patients.

There are various reasons why a patient with SCD can have dental problems namely,

Vaso-occlusion can lead to decreased blood supply to dental apparatus. Asymptomatic pulpal necrosis has been observed in patients with SCA [2]. The patients with SCD have increased risk of osteomyelitis [3-7]. It can sometimes affect the facial bone in addition to the long bones. Vaso-occlusive phenomenon can lead to ischemia and necrosis. Mouth flora can then invade the area $[3,5]$.

Structural changes can occur in bones like mandible and maxilla secondary to hyperplasia and widening of bone marrow space due to increased haematopoiesis [2].

The patient $s$ with SCD has increased risk of infection due to various reasons like- macrophage defects, leukocyte defects and hypo-splenia [3].
Permanent neuropathy affecting mandibular nerve has been reported $[8,9]$. The loss of sensation is thought to be caused by an infarction of the micro-vascular blood supply.

The diagnosis and management of dental problem in can be a difficult process. The visible signs can be absent in SCD [10]. Necrotic pulps often produce radiographic changes that can be used to confirm a diagnosis. Unfortunately, the radiographic changes associated with SCA may mask those alterations [10]. Preventive dental therapy is the ideal approach for management of patients with SCD.

We surveyed a sample of our adult patients with SCD to determine the prevalence of patient reported dental problems, including existing "bad tooth", and tooth abscess. We also investigated the prevalence of dental insurance that pays for regular dental exams.

\section{Methods}

At the Feist-Weiller Cancer Center, adult haematology clinic, we take care of approximately 300 adult patients with SCD. A descriptive study was conducted with a convenience sample of 100 randomly selected adults with SCD. The study design was presented to the Institution Review Board (IRB) and approval was obtained. A grant to conduct the study and hire research assistant was obtained from the cancer institute. An informed verbal and written consent was obtained from the patients who agreed to participate in the study. A research assistant administered a structured interview which included demographic questions and dental health related questions. The demographic variables we collected were- age, gender, race, employment, education, type of SCD, general type of health insurance. The dental heath variables we collected were-dental insurance, last dental exam, number of adult teeth removed, and a patient selfassessment of bad teeth, tooth abscess and number of past episodes of either. 
Page 2 of 3

\section{Results}

The patient demographics are as shown in the Table 1 . The mean age was 33 years with three patients in their 60s. SS was the most common type of SCD. All the subjects were African-Americans and $53 \%$ were female. The rate of employment was very low and a high percentage of SCD patients had a low literacy scores.

\begin{tabular}{|c|c|c|}
\hline Factor & Variable & $\mathbf{N}$ \\
\hline \multirow[t]{3}{*}{ Age } & $18-30$ & 44 \\
\hline & $31-40$ & 40 \\
\hline & $41-66$ & 16 \\
\hline \multirow[t]{3}{*}{ Type of SCD } & SC & 15 \\
\hline & SS & 68 \\
\hline & S Beta Thal & 17 \\
\hline \multirow[t]{2}{*}{ Gender } & Female & 53 \\
\hline & Male & 47 \\
\hline Race & $\mathrm{AA}$ & 100 \\
\hline \multirow{2}{*}{ Employment } & No & 84 \\
\hline & Yes & 16 \\
\hline \multirow[t]{3}{*}{ Education } & College Graduate & 14 \\
\hline & High School Graduate & 37 \\
\hline & Less than high school graduate & 49 \\
\hline \multirow[t]{4}{*}{ General Health Insurance } & Medicaid & 61 \\
\hline & FreeCare & 2 \\
\hline & Medicare & 25 \\
\hline & Private & 12 \\
\hline
\end{tabular}

Table 1: Patient characteristics.

Table 2 displays the results of dental surgery. Only 33 percent of the adults with SCD had the dental insurance. Majority (86\%) of these patients had federally funded insurance as their general health insurance. Only $33 \%$ had their last dental exam within a year. $24 \%$ did not have a dental exam in more than 2 years. A third of them had more than 2 adult teeth removed. $41 \%$ of the patients reported that they currently had tooth ache or have a bad tooth. 33\% reported that they had episodes of tooth abscess or jaw swelling.

\begin{tabular}{|l|l|l|}
\hline \multicolumn{2}{|l|}{ Parameter } & Number of patients \\
\hline \multirow{2}{*}{ Dental Insurance } & Yes & 33 \\
\cline { 2 - 3 } & No & 67 \\
\hline \multirow{2}{*}{ Last Dental Exam } & Less than a year ago & 33 \\
\cline { 2 - 3 } & Between 1-2 years & 43 \\
\cline { 2 - 3 } & $\begin{array}{l}\text { More than 2 years } \\
\text { ago }\end{array}$ & 24 \\
\hline Adult teeth removed & 0 & 43 \\
\hline
\end{tabular}

\begin{tabular}{|l|l|l|}
\hline \multirow{2}{*}{} & $1-2$ & 24 \\
\cline { 2 - 3 } & $>2$ & 33 \\
\hline Tooth ache/bad tooth & $\mathrm{N}$ & 59 \\
\cline { 2 - 3 } & $\mathrm{Y}$ & 41 \\
\hline \multirow{2}{*}{$\begin{array}{l}\text { Tooth abscess or Jaw } \\
\text { swelling }\end{array}$} & $\mathrm{N}$ & 67 \\
\cline { 2 - 3 } $\begin{array}{l}\text { Number of episodes of } \\
\text { tooth abscess or jaw } \\
\text { swelling }\end{array}$ & $1-2$ & 33 \\
\cline { 2 - 3 } & $>2$ & 27 \\
\hline
\end{tabular}

Table 2: Results of the dental survey.

Table 3 shows the statistical analysis of various variables. Gender, type of sickle cell disease, amount of pain medication, health insurance status, and pain medication and how long ago dental exam were related to episodes of tooth ache/bad teeth or tooth abscess/jaw swelling. The adults with dental insurance had fewer episodes of dental abscess/jaw swelling.

\begin{tabular}{|c|c|c|}
\hline Variable & Factor & P Value \\
\hline \multirow[t]{7}{*}{ Tooth ache/Bad Tooth } & Gender & 0.48 \\
\hline & Health Insurance Status & 0.21 \\
\hline & Type of SCD & 0.95 \\
\hline & Dental Insurance & 0.5 \\
\hline & Pain Medication & 0.89 \\
\hline & $\begin{array}{l}\text { How long ago was dental } \\
\text { exam }\end{array}$ & 0.17 \\
\hline & Adult Teeth removed & 0.8 \\
\hline \multirow{7}{*}{$\begin{array}{l}\text { Tooth Abscess/ Jaw } \\
\text { Swelling }\end{array}$} & Gender & 0.83 \\
\hline & Health Insurance Status & 0.22 \\
\hline & Type of SCD & 0.19 \\
\hline & Dental Insurance & $\begin{array}{llll}0.02 \quad(27 & \text { vs } & 6 \\
\text { episodes }) & & \end{array}$ \\
\hline & Pain Medication & 0.87 \\
\hline & $\begin{array}{l}\text { How long ago was dental } \\
\text { exam }\end{array}$ & 0.69 \\
\hline & Adult Teeth removed & 0.44 \\
\hline \multirow[t]{2}{*}{ Gender } & Pain Medication & 0.17 \\
\hline & $\begin{array}{l}\text { How long ago was dental } \\
\text { exam }\end{array}$ & 0.89 \\
\hline Dental Insurance & $\begin{array}{l}\text { How long ago was dental } \\
\text { exam }\end{array}$ & 0.007 (29 m vs $13 \mathrm{~m})$ \\
\hline $\begin{array}{l}\text { Health Insurance } \\
\text { Status }\end{array}$ & $\begin{array}{l}\text { How long ago was dental } \\
\text { exam }\end{array}$ & 0.58 \\
\hline \multirow[t]{2}{*}{ Type of SCD } & Pain Medication & 0.5 \\
\hline & $\begin{array}{l}\text { How long ago was dental } \\
\text { exam }\end{array}$ & 0.5 \\
\hline
\end{tabular}


Page 3 of 3

\begin{tabular}{|l|l|l|}
\hline & Adult Teeth removed & 0.34 \\
\cline { 2 - 3 } & Number of episodes & 0.33 \\
\hline
\end{tabular}

Table 3: Chi Square testing for variables.

\section{Discussion}

Our study shows that dental health is a significant unmet need for adult patients with SCD. The majority do not get regular dental exam and the majority don't have a dental insurance plan to pay for the dental exams. On statistical analysis it was evident that adults with dental insurance had fewer episodes of dental abscess/jaw swelling. We compared the data on dental health from 2010 dental survey results in USA and LA. According to the survey, 23\% of African American people between 35-44 years had destructive periodontal disease and $63 \%$ had lost no teeth among all races in US between 35-44 years. There are very few studies in literature regarding dental health in sickle cell disease. There are no published guidelines for dental health. A Cochrane review did not identify any randomized controlled studies assessing interventions for the treatment of dental complications in people with SCD [11]. Since the dental condition as not life threatening, both patient and physician often treat these problems as trivial and this may lead to neglect. Fear of dental treatment and expense further inhibits patients seeking treatment for dental problems [11]. Lawrence et al. [12] reported that the patients with life threatening hemoglobinopathy like SCD may not regard oral health as a priority, especially among low socio-economic groups. This often leads to worsening of dental complications leading to emergency room evaluations and hospital admission [12]. Previous studies have shown increased risk of dental infections in individuals with SCD sometimes initiating sickle cell crises $[13,14]$. In one study of 55 SCD patients, the parameters of periodontal disease like plaque index, gingival index and bleeding on probing were significantly higher in SCD [15]. Multiple dental problems have been described in literature for SCD patients, like pulpal necrosis [2,16,17], mandibular infarction [16,18], osteomyelitis of mandible [18], increased risk of caries [19], mandibular anaesthesia, [10] facial swelling [20] hypodontia [21]. The radiographs of patients with SCD can show enlarged medullary space, enamel hypo-mineralization, calcification of pulp canals, and mandibular thinning [10]. A pilot case-control study found that due to oral negligence decayed teeth were significantly more prevalent in adults with SCD. The mean number of filled teeth was significantly lower in individuals with SCD due to lack of appropriate and timely treatment. On the survey, authors found that although $92 \%$ of patient with SCD were aware of high risk of tooth decay, they were not able to take timely and appropriate action due to frequent hospitalization and vaso-occlusive crises which deterred them from seeking regular dental consultation [22]. Another study done on a sample of 102 AfricanAmerican adult patients with SCD showed that low-income African Americans with SCD may be at increased risk for dental caries and are less likely to receive treatment with a restoration [19]. Our results are in agreement as majority of patient had dental problems, low formal education achievement and only $16 \%$ were employed. The educational level and lack of social support might lead to decreased awareness about dental hygiene in this population.

\section{Conclusion}

In our surveyed population of adult patients with SCD, we find a high rate of self-reported advanced dental disease and failure to obtain regular dental care. Dental heath remains an unmet need for adult patients with SCD. Majority do not have dental insurance for regular dental evaluations.

\section{References}

1. Platt OS (1994) Mortality in sickle cell disease. Life expectancy and risk factors for early death. N Engl J Med 330: 1639-1644.

2. Andrews CH, England MC, Kemp WB (1983) Sickle cell anaemia: An etiological factor in pulpal necrosis. J Endod 9: 249-252.

3. Patton LL, Brahim JS, Travis WD (1990) Mandibular osteomyelitis in a patient with sickle cell anemia: Report of case. J Am Dent Assoc 121: 602-604.

4. Shroyer JV (1991) Osteomyelitis of the mandible as a result of sickle cell disease. Oral Surg Oral Med Oral Pathol 72: 25-28.

5. Ryan MD (1971) Osteomyelitis associated with sickle-cell anaemia. Report of a case. Oral Surg Oral Med Oral Pathol 31: 754-759.

6. Golding JS (1956) The bone changes in sickle cell anaemia. Ann R Coll Surg Engl 19: 296-315.

7. Engh CA (1971) Osteomyelitis in the patient with sickle-cell disease. J Bone Joint Surg Am 53: 1-15.

8. Gregory G, Olujohungbe A (1994) Mandibular nerve neuropathy in sickle cell disease. Oral Surg Oral Med Oral Pathol 77: 66-69.

9. Friedlander AH, Genser L, Swerdloff M (1980) Mental nerve neuropathy: A complication of sickle-cell crisis. Oral Surg Oral Med Oral Pathol 49: 15-17.

10. Kelleher M, Bishop K, Briggs P (1996) Oral complications associated with sickle cell anaemia. Oral Surg Oral Med Oral Pathol Oral Radiol Endod 82: 225-228.

11. Mulimani P (2016) Treatment of dental complications in sickle cell disease. Cochrane Database Syst Rev 4: CD011633.

12. Laurence B, Haywood C, Lanzkron S (2013) Dental infections increase the likelihood of hospital admissions among adult patients with sickle cell disease. Community Dent Health 30: 168-172.

13. O'Rourke C, Mitropoulos C (1990) Orofacial pain in patients with sickle cell disease. Br Dent J 169: 130-132.

14. Rada RE, Bronny AT, Hasiakos PS (1987) Sickle cell crisis precipitated by periodontal infection: report of two cases. J Am Dent Assoc 114: 799-801.

15. Guzeldemir E, Toygar HU, Boga C, Cilasun U (2011) Dental and periodontal health status of subjects with sickle cell disease. J Dent Sci 6: 227-234.

16. Tsatala SK (2004) Mandibular lesions of vasoocclusive origin in sickle cell hemoglobinopathy. Odontology 92: 68-72.

17. Kaya AD, Aktener BO, Unsal C (2004) Pulpal necrosis with sickle cell anaemia. Int Endod J 37: 602-606.

18. Bishop K, Briggs P, Kelleher M (1995) Sickle cell disease: a diagnostic dilemma. Int Endod J 28: 297-302.

19. Laurence B (2006) The association between sickle cell disease and dental caries in African Americans. Spec Care Dentist 26: 95-100.

20. Scipio JE (2001) Facial swelling and gingival enlargement in a patient with sickle cell disease. Oral Dis 7: 306-309.

21. Oredugba FA (2005) Hypodontia in an adolescent with the HbSC genotype: A case report. Int J Paediatr Dent 15: 455-458.

22. Alawi HA (2015) The association between dental and periodontal diseases and sickle cell disease. A pilot case-control study. Saudi Dent J 27: 40-43. 